\title{
Performance Evaluation of a Single Cylinder Spark Ignition Engine Fuelled by Mixing Ethanol and Gasoline
}

\section{OLAWORE, AS; OSENI, WI; *OLADOSU, KO; FADELE, EO}

\author{
Department of Mechanical Engineering, Kwara State University, Malete, Kwara State, Nigeria
}

*Corresponding Author Email: kamoru.oladosu@kwasu.edu.ng

\begin{abstract}
The use of ethanol blend as an alternative source of fuel for developing clean and sustainable energy sources has grown considerably. In this study, the performance characteristics of an air-cooled, single-cylinder 4-stroke Spark Ignition (SI) engine (TD201) with a compression ratio of 8.5:1 was determined using gasoline and different blend ratios of ethanol and gasoline (E0, E2, E4, E6, E8, E10, and E12) at a varied engine speed of 2000rpm, 2200rpm, 2400rpm, 2600rpm and $2800 \mathrm{rpm}$. The results revealed that as the ethanol content of the blend increases, the heating value decreases while octane value increases. The experimental results indicated that the brake torque, and power increase as the ethanol content in the blends increases. However, BSFC and exhaust temperature decreases as the ethanol content in the blends increases because of the oxygen enrichment. The emissions of unburned hydrocarbon and carbon monoxide reduce while carbon dioxide and ethanol content increases when compared with the reference fuel (E0).
\end{abstract}

\section{DOI: https://dx.doi.org/10.4314/jasem.v25i6.14}

Copyright: Copyright $\odot 2021$ Olawore et al. This is an open access article distributed under the Creative Commons Attribution License (CCL), which permits unrestricted use, distribution, and reproduction in any medium, provided the original work is properly cited.

Dates: Received: 20 March 2021; Revised: 27 April 2021; Accepted: 07 May 2021

Keywords: Ethanol, Emission, Calorific value, Renewable.

Internal combustion (IC) engines are chiefly responsible for the emission of hazardous gases which have effects on the environment and human body such as the greenhouse effect, acid rain, global warming, and other harmful effects. The search for alternative fuel over conventional petroleum-based fuels is being considered for the possibility of reducing emission, drop in fuel prices, improved fuel availability, providing clean energy, and reduced reliance on fossil fuel (Koç et al., 2009; Wallner and Miers, 2018). Ethanol and gasoline/diesel blended with alcohol have recently been taken into consideration in minimizing emissions from IC engines due to government policies around the globe. Thus, alternative fuels are being utilized to reduce the effect of global warming and climate change (Ahmed, 2013; Al-Hasan, 2003). Thwarting of engine knock (Wallner et al., 2009), reduction in fuel consumption, increase in engine efficiency and compression ratio are the benefits of using ethanol as a fuel for automobiles (Ahmed, 2013). Ethanol is a renewable fuel that can be produced from different types of raw materials such as waste biomass, cassava, maize, sugar cane, sorghum, agricultural residues among others (Al-Hasan, 2003; Al-Hassan et al., 2012; Koç et al., 2009). Ethanol is used as an oxygenated additive for standard gasoline. This can serve as a substitute or replacement for methyl-butyl ether (MTBE), which has been effectively banned because it possesses human carcinogen(Ahmed,
2013). Ethanol possesses suitable properties for spark ignition (SI) engines in terms of the octane number. The motor octane number (MON) and research octane number (RON) for ethanol are 90 and 109 respectively (Shen et al., 2011). Ethanol and gasoline have boiling temperatures of $64.7^{\circ} \mathrm{C}$ and $40^{\circ} \mathrm{C}$ respectively (Chen and Nishida, 2014). Gasoline is a hydrocarbon $\left(\mathrm{C}_{4-}\right.$ $\mathrm{C}_{12}$ ) that has a multi boiling point between 27 and $225^{\circ} \mathrm{C}$ (Cooney et al., 2009). The addition of more alcohol content in the gasoline blend tends to have adverse effects on cold start and cold idle conditions due to the high content of alcohol that reduces fuel vapor pressure. Consequently, there would be incomplete combustion due to the lean fuel-air mixture (Waluyo et al., 2018). Many researchers have studied the effects of using gasoline blended with alcohol as an alternative fuel on exhaust emission and engine performance. Pikonas et al. (2003) studied the influence of gasoline-ethanol blend composition on parameters of IC engine. The results showed that the addition of ethanol to gasoline has considerable effects on the performance characteristics and emission of gases on the blended fuel. The heating values of the blended fuel decreased as the concentration of ethanol increased whilst the octane number, engine power, and specific fuel consumption increase. Hubballi and Ashok Babu (2012) experimentally analysed the effect of aqueous denatured spirit on exhaust emissions of a four-stroke SI engine. The $\mathrm{CO}$ and $\mathrm{HC}$ emission

*Corresponding Author Email: kamoru.oladosu@kwasu.edu.ng 
decreases drastically as a result of the leaning effect caused by ethanol addition. Bayraktar (2005) studied the use of gasoline-ethanol blends in SI engines. The experiments were conducted with the engine speed of $1500 \mathrm{rpm}$ on full throttle settings at compression ratios of 7.75 and 8.25 . The blend of $7.5 \%$ ethanol was the most suitable one in terms of engine performance and CO emission. Jacobson (2009) studied the effects of biofuel on air pollution and global warming. The presence of olefins, aromatics, or sulfur in gasoline and diesel contributes negatively to the air quantity. However, these components are absent in ethanol. Ethanol may be blended with gasoline or diesel to reduce the effect of the harmful substances through dilution (Masum et al., 2015). Wu et al. (2004) experimentally analysed engine performance and pollutant emission of SI engine under the influence of different air-fuel equivalence ratios using ethanolgasoline-blended fuels. The study revealed that the torque output increased slightly at small throttle valve opening when using ethanol-gasoline-blended fuel and the emissions of $\mathrm{CO}$ and $\mathrm{HC}$ reduce with an increase in ethanol content of the blended fuel, which resulted from oxygen enrichment. Virendra and Rawat (2015) studied the effect of compression ratio on the emission of the pollutant of a four-stroke singlecylinder SI engine using different ethanol-gasoline blends (E0, E10, E20, E30, and E40). The results showed that the emission of unburned $\mathrm{HC}$ and $\mathrm{CO}$ decreased while increasing the compression ratio. This research aims to investigate the performance and exhaust emissions of gasoline blended with distilled ethanol blends using a four-stroke SI engine. The objective of the research is to determine the effects of base fuel (E0) and ethanol blends (E2, E4, E6, E8, E10, and E12) on brake torque, power, BSFC and exhaust emissions of a 4-stroke, single-cylinder, and air-cooled gasoline engine with a compression ratio of 8.5:1 at WTO.

\section{MATERIALS AND METHODS}

Preparation of fuel: In this study, pure gasoline with an octane number of 91 was chosen as the base fuel. Ethanol (99.7\% purity) and gasoline were mixed with different proportions using a magnetic stirrer and beaker to form different blends. The gasoline with $0 \%$ ethanol (E0) is the control sample. The properties of the gasoline are listed in Table 1. The compositions of the blends were obtained by mixing ethanol with gasoline as shown in Table 2.

Characterization of ethanol and its blends: The calorific value of the distilled ethanol and its blends were determined using an oxygen bomb calorimeter 6100 made by Parr Instrument, Illinois. The test was done according to the standard procedure of ASTM
D2382-88. The octane ratings for the blends were determined using Octane analyser. Hanna multiparameter $9813-6 \mathrm{~N}$ was used to determine the $\mathrm{pH}$ value of ethanol according to ASTM V96. The flashpoint of the ethanol was determined according to the ASTM D93 open cup method using a flash point tester. The cloud point of the ethanol was determined according to the ASTM D 5773 method using the cloud point tester apparatus. The equipment is situated at the Department of Chemical Engineering, University of Ilorin. The pour point of the ethanol was determined according to the ASTM D 97-96a method using a fire point tester.

Table 1: Parameters of neat gasoline (Koç et al., 2009; Faruq et

\begin{tabular}{ll}
\multicolumn{2}{c}{$a l ., 2012)$} \\
\hline Parameter & Petrol \\
\hline Colour & Crystal clear, \\
& light brown \\
Density $\left(\mathrm{g} / \mathrm{cm}^{3}\right)$ & $0.72-0.78$ \\
Purity $(\%)$ & 100 \\
Flash point $\left({ }^{\circ} \mathrm{C}\right)$ & 22 \\
Pour point $\left({ }^{\circ} \mathrm{C}\right)$ & $32-57$ \\
Fire point $\left({ }^{\circ} \mathrm{C}\right)$ & 43 \\
Vapour Pressure $(\mathrm{kPa})$ & 6.73 \\
Octane Number & 91 \\
Latent Heat $(\mathrm{MJ} / \mathrm{kg})$ & 34.5 \\
\hline
\end{tabular}

Table 2: Composition of blended fuel

\begin{tabular}{ll}
\hline Blend & Composition (\% Vol.) \\
\hline E0 & Ethanol 0\% and Gasoline 100\% \\
E2 & Ethanol 2\% and Gasoline 98\% \\
E4 & Ethanol 4\% and Gasoline 96\% \\
E6 & Ethanol 6\% and Gasoline 94\% \\
E8 & Ethanol 8\% and Gasoline 92\% \\
E10 & Ethanol 10\% and Gasoline 90\% \\
E12 & Ethanol 12\% and Gasoline 88\% \\
\hline
\end{tabular}

Test Engine: The engine used in this study was an aircooled, single-cylinder SI engine (TD201) located at the Department of Mechanical Engineering, Kwara State University. The engine's specifications are shown in Table 3.The experimental set up consists of a four-stroke, single-cylinder SI engine coupled with a dynamometer. The small engine test set (TD201), a four-stroke engine, with a compression ratio of 8.5:1 was set to an idle speed that was lower than $1000 \mathrm{rpm}$, which was the chosen starting speed for the tests. The engine was allowed to reach the normal operating temperature. The engine was throttled using the dynamometer control valve to increase the load on the test engine and its speed to the first desired speed of $2000 \mathrm{rpm}$. It was allowed to run at this speed and the time required for consumption of $150 \mathrm{~cm}^{3}$ of fuel was noted by using a stopwatch and BSFC was evaluated. Load at the dynamometer was increased gradually until the spring balance read zero. The brake load was recorded accordingly. The engine test was run with neat gasoline at $2000 \mathrm{rpm}, 2200 \mathrm{rpm}, 2400 \mathrm{rpm}, 2600$ rpm, and $2800 \mathrm{rpm}$. The blended fuel (E2, E4, E6, E8, 
E10, and E12) was also run at $2000 \mathrm{rpm}, 2200 \mathrm{rpm}$, $2400 \mathrm{rpm}, 2600 \mathrm{rpm}$, and $2800 \mathrm{rpm}$. Torque, engine speed, fuel mass flow rate, and exhaust temperature were measured. A handheld flue gas combustion analyzer (Model 1207A) was used to analyze the exhaust gas emission. It was used to measure the $\mathrm{CO}$, $\mathrm{HC}$, and $\mathrm{CO}_{2}$ emissions at engine speeds of $2000 \mathrm{rpm}$, $2200 \mathrm{rpm}, 2400 \mathrm{rpm}, 2600 \mathrm{rpm}$, and $2800 \mathrm{rpm}$ for E0, E2, E4, E6, E8, E10, and E12 blends.

\begin{tabular}{ll} 
Table 3: Specification of the test engine (TD201) \\
\hline Engine type & 4-stroke, single-cylinder \\
\hline Net power & $4.8 \mathrm{~kW}$ at $3600 \mathrm{rpm}$ \\
& $2.2 \mathrm{~kW}$ at $1800 \mathrm{rpm}$ \\
Maximum torque & $1.35 \mathrm{~kg}-\mathrm{m} / 2500 \mathrm{rpm}$ \\
Bore/Stroke & $70.00 \mathrm{~mm} / 54.00 \mathrm{~mm}$ \\
Displacement vol. & $196 \mathrm{cc}$ \\
Compression ratio & $8.5: 1$ \\
Engine cooling & air cooled \\
Fuel Type & Gasoline \\
& Ethanol mixed of 90\% \\
& unleaded Gasoline and \\
& $10 \%$ Ethyl Alcohol \\
\hline
\end{tabular}

\section{RESULTS AND DISCUSSION}

Characterization of ethanol: The physiochemical properties of the characterised ethanol are summarised in Table 4. Ethanol is colorless and have an affinity for water and readily miscible with gasoline. It also has a density of $0.7876 \mathrm{~g} / \mathrm{cm}^{3}$ while gasoline has a density between $0.72-0.78 \mathrm{~g} / \mathrm{cm}^{3}$. Ethanol and Gasoline are very similar in specific gravity thereby making them very miscible with each other (Srinivasan and Saravanan, 2010). The flashpoint of ethanol produced was $14^{\circ} \mathrm{C}$ while gasoline has $22^{\circ} \mathrm{C}$. This shows that ethanol has the lowest point/flammability at which fuel vapor starts to ignite when in contact with a flame than gasoline. Lower flashpoints are the indicators of good flammability and volatility.

\begin{tabular}{|c|c|}
\hline Parameter & Ethanol \\
\hline Colour & Colourless \\
\hline Density $\left(\mathrm{g} / \mathrm{cm}^{3}\right)$ & 0.7876 \\
\hline Purity $(\%)$ & 99.70 \\
\hline Flash point $\left({ }^{\circ} \mathrm{C}\right)$ & 14 \\
\hline Pour point $\left({ }^{\circ} \mathrm{C}\right)$ & 5 \\
\hline Fire point $\left({ }^{0} \mathrm{C}\right)$ & 47 \\
\hline Vapour Pressure $(\mathrm{kPa})$ & 5.72 \\
\hline Octane Number & 108.6 \\
\hline
\end{tabular}

Calorific and octane value of ethanol and other blends: The calorific value of the ethanol and other blends was determined according to ASTM D2382-88 and the result indicates that the higher ethanol content, the lower the heating value of the blended fuels. In Figure 1, the octane number and calorific value of the ethanol blends increases and decreases respectively as the ethanol content increases. The octane number of blends is higher than that of gasoline. This invariably means that the blends tend to prevent the knocking of engines (Koç et al., 2009; Faruq et al., 2012). The heating value of gasoline (E0) as indicated in Figure 1 is higher than the other blends. The addition of ethanol to gasoline decreases its calorific value and this increases the power and torque of the engine at varying speeds.

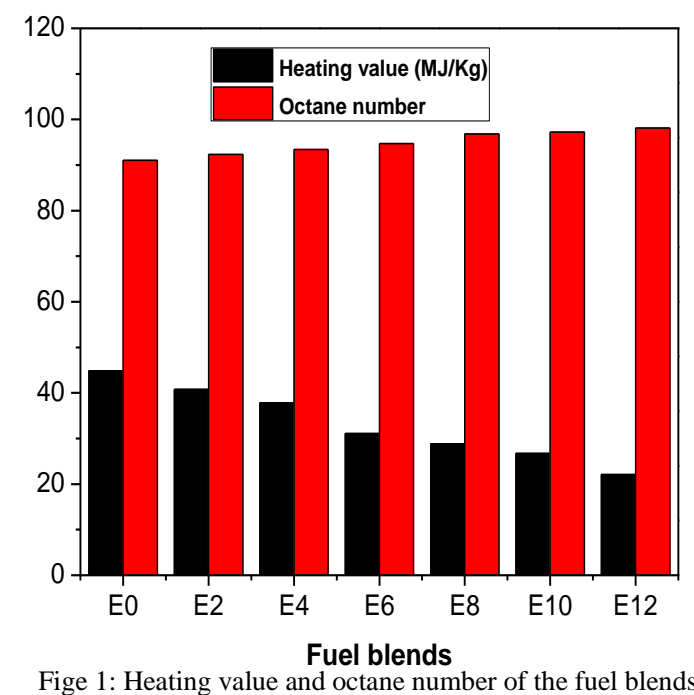

Performance characteristics of the engine: Brake torque and power: The effect of ethanol addition to base gasoline on engine torque and power at the varied speeds of 2000, 2200, 2400, 2600, and $2800 \mathrm{rpm}$ with the compression ratio of 8.5:1 is shown in Figure 2 and Figure 3 respectively. The torque of the blended fuels is higher than the base gasoline at the engine speed range. The presence of ethanol in the blend serves as oxygenated additives to the base fuel and this leads to more complete combustion of the fuel. This invariably increases the torque and power of the engine using the ethanol-blended fuel when compared to the base fuel (Koç et al., 2009). The maximum torque is attained with fuel E12 for the speed range. The torque of the engine reduces for each fuel as the speed of the engine increases. Also, the torque of the engine increases as the ethanol content of the blends increases at the same engine speed. The power decreases at higher engine speed due to friction losses. The relationship between the brake torque and engine speed in this study tally with the result obtained by Phuangwongtrakul et al. (2016).

Brake specific fuel consumption: The variation in BSFC of the engine using different ethanol-gasoline blends for engine speeds at a compression ratio of 8.5:1 is depicted in Figure 4.The BSFC decreases as the ethanol content of the blend increases. The blending of ethanol with gasoline shows lower specific fuel consumption when compared to base gasoline 
because it has oxygen content that aids complete combustion to take place in combustion chamber (Billah et al., 2014; Koç et al., 2009). The BSFC slightly increases with the further increase in engine speeds for the blends.

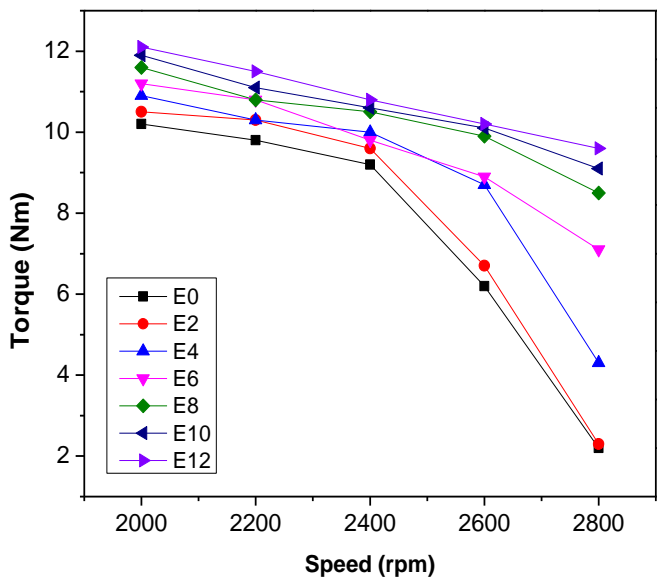

Fig 2: Maximum torque at different engine speeds for the fuel blends

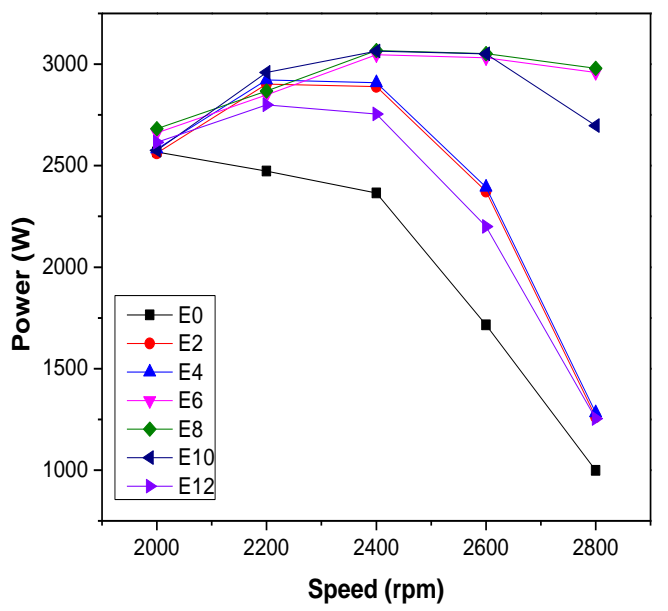

Fig 3: Brake power at different engine speeds for the fuel blends.

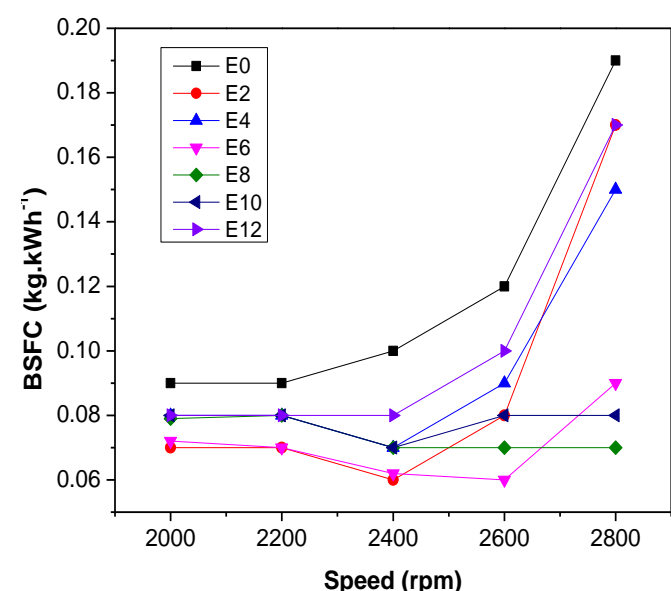

Fig 4: Brake Specific Fuel Consumption at different engine speeds for the fuel blends
Exhaust Temperature: The effect of exhaust gas temperature on ethanol blends at varied engine speed is shown in Figure5. An increase in engine speed for each of the blends resulted in higher exhaust gas temperature. The higher exhaust temperature obtained from increasing the engine speed is due to additional fuel being injected into the combustion chamber during the induction stroke (Abdullah et al., 2015). This consequently produced more heat and power during the combustion process. Thus, the temperature of exhaust gas emitted from the engine increased. Figure 5 also depicts that the higher the ethanol contents of the blends, the lower the exhaust gas temperature of the blends. The exhaust temperature of the base gasoline is slightly higher than the ethanol blends due to the lower calorific value of ethanol (Vivek and Gupta, 2016).

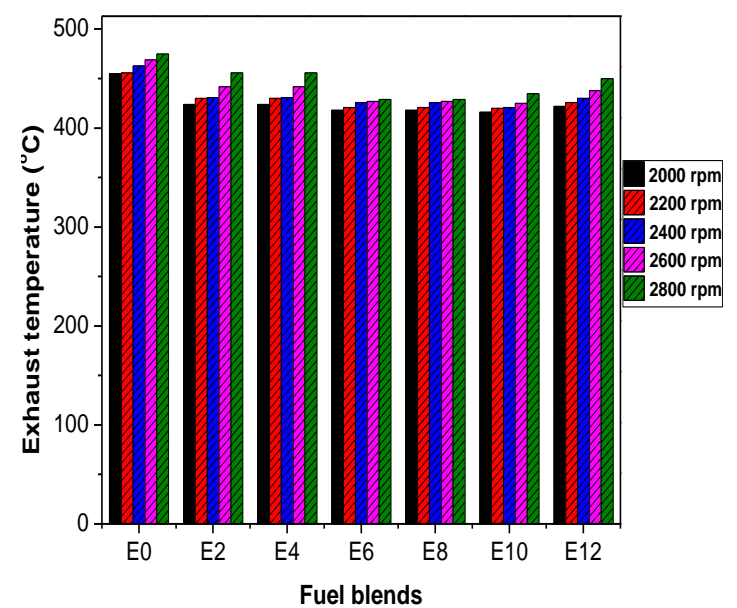

Fig 5: Exhaust temperature of the engine at different speeds for the fuel blends

Exhaust gas emission: Carbon monoxide (CO): Figure6 illustrates the emission of $\mathrm{CO}$ using ethanolgasoline blends at varying engine speeds. The ethanol blends have lesser $\mathrm{CO}$ emission at the same speed when compared with gasoline. The $\mathrm{CO}$ emission slightly decreased when the engine speed increases. The emission of CO slightly decreases as a result of the leaning effect caused by the addition of ethanol in the gasoline which consequently caused more complete combustion. Therefore, completing the oxidation of $\mathrm{CO}$ to $\mathrm{CO}_{2}$ because of the oxygenated effect of ethanol in the fuel blends (Abdullah et al., 2015).

Unburned hydrocarbon: The emissions of unburned $\mathrm{HC}$ at varying engine speeds for different blends with a compression ratio of 8.5:1 are in shown Figure 7. The yield of $\mathrm{HC}$ reduces as the speed of the engine increases. The turbulence intensity of the compressed charges increases at higher engine speeds and more 
complete combustion is achieved. Also, the concentration of unburned $\mathrm{HC}$ decreases as the ethanol content of the blends increases. The yields of unburned $\mathrm{HC}$ of the ethanol blends are lower than that of the gasoline E0.This is due to the leaning effect and oxygen enrichment caused by the ethanol addition to gasoline (Koç et al., 2009).

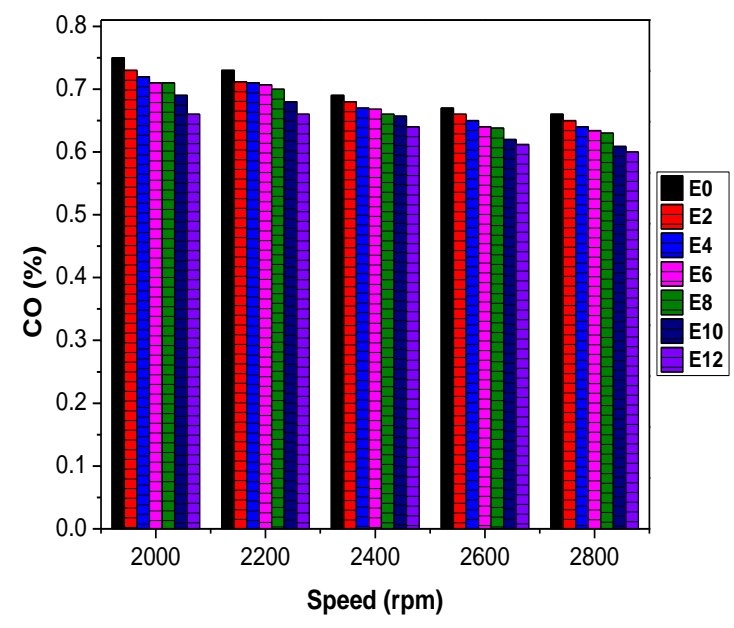

Fig 6: Emission of $\mathrm{CO}$ at different speeds for the fuel blends

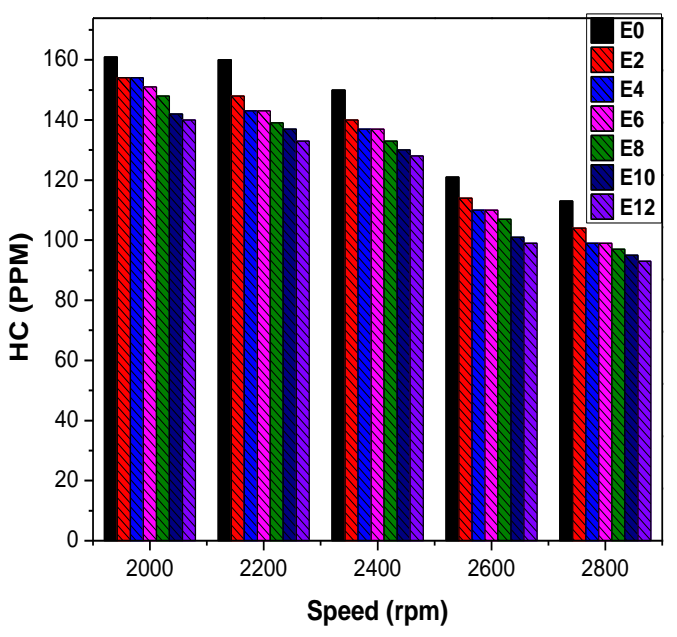

Fig 7: Emission of unburned $\mathrm{HC}$ at different speeds for the fuel blends

Carbon dioxide $\left(\mathrm{CO}_{2}\right)$ : Figure 8 depicts that the emissions of $\mathrm{CO}_{2}$ for ethanol blends are higher than the base gasoline. Gasoline has the lowest content of $\mathrm{CO}_{2}$ when compared with different blend ratios of ethanol at the same speed because of incomplete combustion that might have occurred during the experiment. The increase in the content of ethanol in the blend consequently increases the concentration of $\mathrm{CO}_{2}$ emission. $\mathrm{CO}_{2}$ emission increases because of improved combustion. The emission of $\mathrm{CO}_{2}$ increased as the speed of the engine increases for each of the blends. This is as a result of more complete combustion that took place with sufficient oxygen combining with carbon residue to form $\mathrm{CO}_{2}$ (Abdullah et al., 2015).

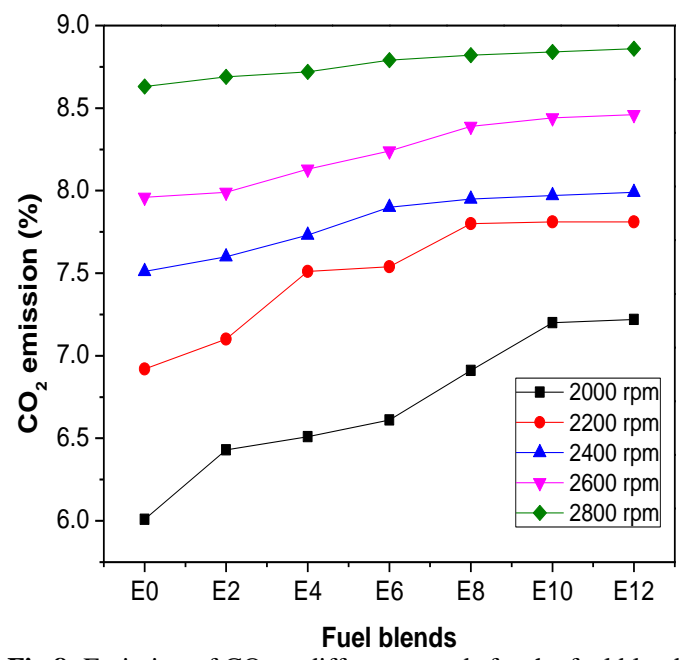

Fig.8: Emission of $\mathrm{CO}_{2}$ at different speeds for the fuel blends

Conclusion: In this study, the effect of base fuel and ethanol blends on performance characteristics and exhaust emissions of a 4-stroke, single-cylinder, and air-cooled gasoline engine with a compression ratio of 8.5:1 at WTO were experimentally investigated. The use of ethanol blends as alternative fuel over fossil fuels provides clean energy with increased $\mathrm{CO}_{2}$ and reduced emission of $\mathrm{HC}$ and $\mathrm{CO}$. This was due to the leaning effect and oxygen enrichment caused by the addition of ethanol to gasoline for more complete combustion to take place.

\section{REFERENCES}

Abdullah, NR; Zaharin, MSM; Mamat, AMI; Nawi, MRM; Sharudin, H (2015). Effects of ethanol blends on gasoline engine performance and exhaust emissions. J. Teknologi. 76(11): 107-112.

Ahmed, SS (2013). Effect of methanol-gasoline blends on s.i. engines performance and pollution. Inter. J. Mech. Mechatronics Eng.. 13(5), 50-53.

Al-Hasan, M (2003). Effect of ethanol-unleaded gasoline blends on engine performance and exhaust emission. Energy Con. Manage. 44(9). 1547-1561.

Al-Hassan, M; Mujafet, H; Al-Shannag, M (2012). An experimental study on the solubility of a dieselethanol blend and on the performance of a diesel engine fueled with diesel-biodiesel-ethanol blends. Jordan J. Mech. Indust. Eng. 6(2): 147-153.

Bayraktar, H (2005). Experimental and theoretical investigation of using gasoline-ethanol blends in 
spark-ignition engines. Renewable Energy. 30(11): 1733-1747.

Billah, M; Hassan, MH; Kalam, A; Sarker, P (2014). Effect of alcohol-gasoline blends optimization on fuel properties and their effect on SI engine performance and emission. J. Cleaner Prod. 86(1): 230-237.

Chen, R; Nishida, K (2014). Spray evaporation of ethanol-gasoline-like blend and combustion of ethanol-gasoline blend injected by hole-type nozzle for direct-injection spark ignition engines. Fuel. 134(1): 263-273.

Cooney, CP; Yeliana, R; Worm, JJ; Naber, JD (2009). Combustion characterization in an internal combustion engine with ethanol - Gasoline blended fuels varying compression ratios and ignition timing. Energy and Fuels. 23(5): 2319-2324.

Hubballi, PA; Ashok Babu, TP (2012). Effect of aqueous denatured spirit on engine performance and exhaust emissions. Proceedings of the 2011 International Conference and Utility Exhibition on Power and Energy Systems: Issues and Prospects for Asia, ICUE 2011: 1-5.

Jacobson, MZ (2009). Effects of biofuels vs. other new vehicle technologies on air pollution, global warming, land use and water. In Inter. J. Biotech. 11(1/2): 14-59.

Koç, M; Sekmen, Y; Topgül, T; Yücesu, HS (2009). The effects of ethanol-unleaded gasoline blends on engine performance and exhaust emissions in a spark-ignition engine. Renewable Energy. 34(10): 2101-2106.

Lynd, LR (1996). Overview and evaluation of fuel ethanol from cellulosic biomass: Technology, economics, the environment, and policy. In Annual Rev. Energy. Environ. 21(1): 403-465.

Masum, BM; Masjuki, HH; Kalam, MA; Palash, SM; Habibullah, M (2015). Effect of alcohol-gasoline blends optimization on fuel properties, performance and emissions of a SI engine. J. Cleaner Prod. 86(1): 230-237.

Phuangwongtrakul, S; Wechsatol, W; Sethaput, T; Suktang, K; Wongwises, S (2016). Experimental study on sparking ignition engine performance for optimal mixing ratio of ethanol-gasoline blended fuels. Appl. Therm. Eng. 100(5): 869-879. composition of gasoline - ethanol blends on parameters of internal combustion engines. $J$. KONES, 10 (1): 205-211.

Prasad, S; Singh, A; Joshi, HC (2007). Ethanol as an alternative fuel from agricultural, industrial and urban residues. In Res. Conserve. Recyc. 50(1): 1-39.

Shen, L; Lei, J; Bi, Y (2011). Performance and emission characteristics of diesel engine fueled with ethanoldiesel blends in different altitude regions. J. Biomed. Biotech. 2011(417421): 1-10.

Srinivasan, CA; Saravanan, CG (2010). Study of Combustion Characteristics of an SI Engine Fuelled with Ethanol and Oxygenated Fuel Additives. $J$. Sustainable Energy. Environ. 1 (X), 85-91.

Faruq, UZ; Runde, M; Danshehu, B.G; Yahaya, HN; Zuru, AA; Muhammed, AB (2012). Comparative Studies of Gasoline Samples Used in Nigeria. Nig. J. Basic. Appl. Sci. 20(2): 87-92.

Virendra, SY; Rawat, DS (2015). Performance Evaluation of SI (Spark Ignition) Engine using Ethanol Gasoline Blend at Various Compression Ratio. Inter. J. Eng. Res.Tech. 4(10): 34-40.

Vivek, P; Gupta, VK (2016). Technical Assessment of Performance Emission Characteristics of an SI Engine using Ethanol - Gasoline Blended Fuel. Inter. J. Eng. Res. Tech. 5(1): 422-426.

Wallner, T; Miers, SA (2018). Combustion Behavior of Gasoline and Gasoline / Ethanol Blends in a Modern Direct-Injection 4-Cylinder Engine. SAE Technical Papers, 2008(724).

Wallner, T; Miers, SA; McConnell, S (2009). A comparison of ethanol and butanol as oxygenates using a direct-injection, spark-ignition engine. $J$. Eng.Gas Turb. Power. 131(3): 1-9.

Waluyo, B; Wardana, ING; Yuliati, L; Sasongko, MN (2018). The role of molecule cluster on the azeotrope and boiling points of isooctane-ethanol blend. Fuel. 21(3): 178-186.

Wu, CW; Chen, RH; Pu, JY; Lin, TH (2004). The influence of air-fuel ratio on engine performance and pollutant emission of an SI engine using ethanolgasoline-blended fuels. Atmos. Environ. 38(40): 7093-7100.

Pikonas, A; Grabys, J; Pukalskas, S (2003). Influence of 